Anthropos: Jurnal Antropologi Sosial dan Budaya 4 (2) (2019): 179-187.

DOI: https://doi.org/10.24114/antro.v4i2.11950

\title{
ANTHROPOS:
}

Jurnal Antropologi Sosial dan Budaya

Available online http://jurnal.unimed.ac.id/2012/index.php/anthropos

\section{Peran Mahasiswa Perguruan Tinggi Islam Aceh Tenggara sebagai Agents of Social Change}

\author{
Sahipul Anwar ${ }^{1) *}$, Sahidup Kudadiri2) \& Candra Wijaya ${ }^{3)}$ \\ 1) Sekolah Tinggi Agama Islam Sepakat Segenep Kutacane, Indonesia \\ ${ }^{2)}$ Sekolah Tinggi Agama Islam Al-Ikhlas, Dairi, Sidikalang, Indonesia \\ 3) Manajemen Pendidikan Islam, Fakultas Ilmu Tarbiyah dan Keguruan, \\ Universitas Islam Negeri Sumatera Utara, Indonesia.
}

Diterima: Januari 2019; Disetujui: Januari 2019; Diterbitkan: Januari 2019

\begin{abstract}
Abstrak
Perguruan tinggi berkewajiban melaksanakan pendidikan, penelitian dan pengabdian kepada masyarakat. Melalui tridarma perguruan tinggi mahasiswa sejatinya harus memberikan kontribusi bagi masyarakat. Penelitian ini fokus pada peran mahasiswa perguruan tinggi Aceh Tenggara sebagai Agents of Social Change. Penelitian ini menggunakan metode penelitian kualitatif dengan pendekatan sosiologis. Hasil penelitian ini menunjukkan bahwa mahasiswa perguruan tinggi Islam Aceh Tenggara telah berperan positif terhadap pembentukan kehidupan masyarakat dan mempunyai peranan yang sangat penting, strategis dalam pembentukan moral, akhlak dan etika peserta didik yang sekarang ini sedang berada pada titik terendah dalam perkembangan masyarakat. Peran pendidikan Islam untuk membuat dan menciptakan peserta didik yang berkarakter atau berkepribadian yang Islami, yang merupakan bagian dari masyarakat.
\end{abstract}

Kata Kunci. Perguruan Tinggi Islam, Agents of Social Change.

\begin{abstract}
Higher education is obliged to carry out education, research and community service. Through the tridarma of higher education students must actually contribute to society. This research focuses on the role of Southeast Aceh university students as Agents of Social Change. This study uses qualitative research methods with a sociological approach. The results of this study indicate that students of Southeast Aceh Islamic tertiary institutions have played a positive role in the formation of people's lives and have a very important, strategic role in the formation of moral, moral and ethical learners who are currently at the lowest point in community development. The role of Islamic education is to create and create students who are characterized or Islamic in character, who are part of the community.
\end{abstract}

Keywords. Islamic Higher Education, Agent of Social Change.

How to Cite: Anwar, S. Kudadiri, S. Wijaya, C. (2019). Peran Mahasiswa Perguruan Tinggi Islam Aceh Tenggara sebagai Agents of Social Change. Anthropos: Jurnal Antropologi Sosial dan Budaya, 4 (2): 179-187.

\begin{tabular}{lr}
\hline *Corresponding author: & ISSN 2460-4585 (Print) \\
E-mail: sahidupkudadiri@kemenag.go.id & ISSN 2460-4593 (Online)
\end{tabular}




\section{PENDAHULUAN}

Pendidikan dalam perspektif Islam dikenal dengan istilah tarbiyah, ta'lim, ta'dib dan riyadah. Pendidikan Islam dapat diartikan sebagai proses transinternalisasi pengetahuan dan nilai Islam kepada peserta didik melalui upaya pengajaran, pembiasaan, bimbingan dan pengasuhan potensinya guna mencapai keselarasan dan kesempurnaan hidup di dunia dan di akhirat (Mujib, 2006).

Lembaga pendidikan Islam telah memainkan perannya sesuai dengan tuntutan masyarakat dan zamannya (Nizar, 2005). Perkembangan lembaga pendidikan Islam telah menarik perhatian para ahli, baik dari dalam maupun luar negeri untuk melakukan studi ilmiah secara komprehensif. Hal ini akan memperkaya khazanah ilmu pengetahuan yang bernuansa keislaman, juga sebagai bahan rujukan dan perbandingan bagi para pengelola pendidikan Islam pada masa-masa berikutnya.

Pendidikan dianggap merupakan persyarat dan kondisi yang mutlak untuk menjalankan program dan tujuan-tujuan dari pendidikan terhadap masyarakat. Tanpa pendidikan sulit bagi masyarakat manapun untuk mencapai kemajuan. Karena itu banyak ahli pendidikan yang berpandangan bahwa "pendidikan merupakan kunci yang membuka pintu ke arah peradaban yang maju. Oleh karena itu, pendidikan harus diperbaharui atau dimodernisasi, sehingga dapat memenuhi harapan dan fungsi yang dipikulkan kepadanya.

Pendidikan Tinggi secara kulturan pada umumnya berada dalam lingkup peran, fungsi dan tujuan yang tidak berbeda. Semuanya hidup dalam upaya yang bermaksud mengangkat dan menegakkan martabat manusia melalui transmisi yang dimilikinya, terutama dalam bentuk transfer of knowledge dan transfer of values. Dalam konteks ini secara jelas juga menjadi sasaran jangkauan pendidikan Islam, merupakan bagian dari sistem pendidikan nasional, sekalipun dalam kehidupan bangsa Indonesia tampak sekali eksistensinya secara cultural. Tapi secara kuat ia telah berusaha untuk mengambil peran yang kompetitif dalam setting sosiologis bangsa, walaupun tetap saja tidak mampu menyamai pendidikan umumn yang ada dengan otonomi dan dukungan yang lebih luas, dalam mewujudkan tujuan pendidikan secara nyata.
Pendidikan sejatinya berfungsi untuk memberikan keahlian kepada peserta didik yang berguna bagi lingkungan sosio-kulturnya. Lembaga pendidikan harus memberikan peserta didik kualifikasi-kualifikasi pekerjaan dan profesi yang akan membuat mereka mampu memainkan peran dalam masyarakat. Di sinilah peran perguruan tinggi dalam menyeimbangkan kualifikasi peserta didik dengan kebutuhan masyarakat sesuai dengan tujuan yang ingin dicapai. Perguruan tinggi merupakan suatu lembaga yang bertujuan untuk menghasilkan SDM yang berkualitas agar dapat mengabdi di masyarakat. Dengan pengabdian tersebut budaya di masyarakat dapat berlanjut ke generasi selanjutnya. Hal ini sejalan dengan pendapat At-Toumy, bahwa pendidikan adalah proses transformasi kebudayaan yang diusahakan, baik dalam tingkah laku individu, kehidupan masyarakat dan alam sekitar individu itu hidup (AtToumy,1979).

Dari penjelasan singkat di atas, tampak jelas bahwa sejatinya masyarakat harus menyadari bahwa proses pendidikan itu bukan terbatas pada pengembangan aspek material saja. Maksudnya, konsep pendidikan itu identik dalam masyarakat sebagai alat untuk mendapatkan materi saja. Pola pikir inilah yang harus dihilangkan di masyarakat dengan menanamkan konsep pendidikan yang benar, yaitu sebagai pembentukan insan kamil yang selamat dunia dan akhirat.

Mahasiswa yang mengenyam pendidikan di perguruan tinggi sangat berperan memberikan pengaruh kepada masyarakat. Peran yang disandang pemuda Indonesia sebagai agen perubahan (Agent of Change) dan agen kontrol social (Agent of Social Control) hingga saat ini masih sangat efektif dalam memposisikan peran pemuda Indonesia dalam masyarakat. (Suharyanto, Armansyah, \& Taufik, 2016). Jika masyarakat menganggap pendidikan merupakan kegiatan yang tidak memberikan dampak perubahan terhadap kehidupan, maka mereka akan cendrung apatis terhadap hasil pendidikan.

Di sinilah mahasiswa harus bekerja keras sebagai Agents of Social Change agar pendidikan selalu subur di masyarakat, khususnya di Aceh Tenggara merupakan masyarakat yang lebih kental dengan konsep pertanian. Masyarakat Aceh Tenggara kurang simpati dengan pendidikan. Ada kata-kata yang sering menjadi pembicaraan 
masyarakat bahwa "Untuk apa sekolah? Toh sekolah pun ujung-ujungya mencari uang juga. Lebih baik dari muda mencari uang." Jika ini menjadi budaya di masyakat, maka masyarakat akan makin jauh dari keinginan untuk berubah dengan pendidikan.

Berdasarkan latar belakang tersebut, penulis ingin memberikan gambaran bagaimana peran mahasiswa perguruan tinggi Islam di masyarakat Aceh Tenggara sebagai Agents of Social Change.

\section{METODE PENELITIAN}

Penelitian ini adalah penelitian kualitatif (qualitative research). Istilah penelitian kualitatif dimaksudkan sebagai jenis penelitian yang temuantemuannya mengutamakan proses dan tidak diperoleh melalui prosedur statistik atau bentuk hitungan angka. Seperti penelitian tentang kehidupan, riwayat, dan perilaku seseorang, peranan organisasi, gerakan sosial, atau hubungan timbal-balik (Suwandi, 2008).

Penelitian ini menggunakan pendekatan sosiologis. Kuntowijoyo mengatakan penelitian sosiologis sangat erat hubungannya dengan lembaga sosial. Kuntowijoyo mengatakan lembaga sosial bisa menjadi sebuah kajian. Banyak tema dan topik yang bisa dibicarakan, seperti perubahan sosial dilihat dari segi model evolusi sejarah yang terjadi pada perubahan pendidikan seperti pesantren, madrasah, maupun sekolah (Kuntowijoyo, 2003).

Peneliti mengumpulkan semua saksi mata yang mengetahui tentang periode sejarah tersebut. Dengan adanya saksi mata tersebut akan menyiapkan bagi peneliti untuk menerima informasi yang diperlukan (Kuntowijoyo, 2003: 74). Dalam hal ini peneliti akan mengumpulkan sumber-sumber data yang berkaitan dengan penelitian ini. Untuk mengumpulkan data-data tersebut, penulis menggunakan beberapa teknik dalam pengumpulan data, yaitu observasi, dokumentasi dan wawancara.

\section{HASIL DAN PEMBAHASAN}

\section{Hakikat Pendidikan dalam Perguruan Tinggi}

Defenisi pendidikan Agama Islam banyak para pakar pendidikan Islam antara lain (Langgulung: 1987): Menurut Zuhairini dkk. Ialah usaha-usaha secara sistematis dan pragmatis membentuk anak didik supaya mereka hidup sesuai dengan ajaran Islam.

Menurut Marimba pendidikan Islam adalah bimbingan jasmani-rohani berdasarkan hukumhukum agama Islam menuju kepada pembentukan keperibadian utama menurut ukuran-ukuran Islam.

Sedangkan Perguruan Tinggi Islam itu sendiri merupakan satuan pendidikan yang menyelenggarakan pendidikan tinggi berupa akademi, politeknik, sekolah tinggi, institut atau universitas. Perguruan tinggi itu sendiri berkewajiban pendidikan, penelitian dan pengabdian kepada masyarakat (Syahrizal, 2008). Masyarakat adalah sejumlah manusia yang merupakan satu kesatuan golongan yang berhubungan tetap dan mempunyai kepentingan yang sama. Seperti; sekolah, keluarga, perkumpulan, negara semua adalah masyarakat

Dalam ilmu sosiologi kita mengenal ada dua macam masyarakat, yaitu masyarakat paguyuban dan masyarakat petambayan. Masyarakat paguyuban terdapat hubungan pribadi antara anggota-anggota yang menimbulkan suatu ikatan batin antara mereka. Kalau pada masyarakat patambayan terdapat hubungan pamrih antara anggota-angotanya. Di sinilah diperlukan peran perguruan tinggi Islam dalam membina masyarakat yang mempunyai kepribadian yang sesuai dengan tuntunan Islam.

Sebagaimana telah kita ketahui selama ini, bahwa secara harfiah perguruan tinggi di Indonesia memiliki peranan sebagai pilar dan fundamen dalam proses transformasi peradaban bangsa, yang secara praktis pada manifestasinya dilakukan dalam bentuk pendidikan, penelitian dan pengabdian masyarakat. Indonesia memerlukan suatu perguruan tinggi yang dapat diandalkan dalam kompetisi global, dan itu merupakan faktor penting dalam memulai suatu perubahan untuk memperbaiki kualitas para sarjana di tanah air. Kalau dipersempit lagi bahwa di Aceh Tenggara khususnya masih banyak lahan garapan untuk penelitian sebagai konstribusi untuk masyarakat Aceh Tenggara. Namun, hingga kini masih terdapat pertanyaan yang belum terjawab. Sekalipun ada, itu tidak sebanding dengan jumlah lulusan yang dihasilkan setiap tahunnya. Ketidakmampuan bersaing ini disebabkan karena terdapat kesenjangan antara kualifikasi yang diperlukan dengan kompetensi lulusan. Idealnya suatu 
perguruan tinggi harus dapat menyiapkan lingkungan belajar yang kondusif untuk terbentuknya kompetensi tersebut sehingga pada akhirnya peran dan fungsi mahasiswa dalam menjaga kedaulatan bangsa dan negara dapat teraplikasikan dengan optimal.

Mahasiswa mempunyai kedudukan yang sangat unik, yaitu sebagai kaum yang diterima oleh semua lapisan masyarakat dan mempunyai kemampuan intelektual yang tinggi. Keberadaan tersebut juga didukung oleh karakteristik mahasiswa yang rata-rata masih berusia muda, penuh semangat, dinamis dan tidak akut kehilangan yang merusak idealisme diri. Karena itulah di lingkungan mahasiswa sering disebut mahasiswa sejati. Ketika terjun ke masyarakat, mereka dapat dengan mudah berbaur dan ketika harus berurusan dengan kaum birokrat mereka mampu mengimbangi dengan kemampuan intelektual dan pendidikannya selama ini. Oleh sebab itu, mereka berperan strategi dalam kehidupan berbangsa, yaitu sebagai penerus citacita bangsa.

Peran mahasiswa sendiri di dalam menjaga kedaulatan bangsa Indonesia cukup penting, khususnya dalam bidang riset dan teknologi. Di bidang teknologi, peran mahasiswa penting untuk mendukung pembangunan infrastuktur nasional, misalnya dalam pembangunan jembatan. Seorang mahasiswa, khususnya yang berkecimpung di bidang teknik sipil seharusnya memiliki pengetahuan yang menyeluruh, dan tidak hanya memiliki intellegent yang baik, tetapi juga harus memiliki skill dan attitude sehingga dalam penerapan dalam kehidupan nyata, mereka dapat menjadi ujung tombak dalam pembangunan infrastuktur di Indonesia.

Terbentuknya masyarakat seutuhnya yang berkualitas unggul yang berkembang dan tumbuh di atas pola kehidupan yang seimbang antara lahiriah dan batiniah, antara jasmani dan rohaniah atau antara kehidupan mental spiritual dan fisik material. Dalam bahasa Islam, membentuk insan kamil yang dapat mengembangkan dirinya dalam pola kehidupan yang kahasanah fiddunnya dan khasanah fil akhirat terhindar dari siksaan api neraka, secara simultan tidak terpisah-pisah antara kedua unsurnya. Pendidikan harus berorientasi kepada hubungan tiga arah, yaitu hubungan anak didik dengan Tuhannya, dengan masyarakat dan dengan alam sekitarnya.

Mahasiswa sebagai agen perubahan merupakan suatu hal yang penting karena tugasnya sebagai tridarma perguruan tinggi. Ketika ingin melakukan suatu perubahan sudah tentu banyak kendala yang dihadapi. Hal ini setidaknya sejalan dengan faktor-faktor yang diperlukan untuk melancarkan proses perubahan di masyarakat adalah antara lain sebagai berikut (Thoha, 2007): a) Motivasi memegang peranan yang penting dalam menjamin kelancaran suatu perubahan. Setiap orang yang memutuskan untuk berubah harus memiliki motivasi yang kuat untuk berubah. Tujuan yang besar hanya bisa dicapai dengan bermodalkan motivasi yang kuat. Semakin besar tujuan perubahan yang ingin dicapai, semakin besar pula modal motivasi yang harus disiapkan oleh mahasiswa; b) Tujuan yang ingin dicapai dengan melaksanakan perubahan harus didefinisikan dengan jelas di awal.Setelah tujuan perubahan yang ingin dicapai seseorang sudah terdefinisi dengan jelas, langkah berikutnya yang perlu dilakukan adalah mengidentifikasi peran dan tujuan dari masing-masing individu dalam perubahan tersebut; c) Buatlah rencana perubahan yang akan dilakukan untuk memastikan tujuan yang sudah ditetapkan dapat tercapai. Rencana ini sangat penting karena goal without a plan is just a wish; d) Faktor keempat ini lah yang akan menentukan berhasil tidaknya suatu perubahan karena sesuatu hanya akan terwujud karena adanya tindakan.Tidak ada suatu keberhasilan besar yang muncul tanpa disiplin dan fokus dalam action karena kalau kita menginginkan suatu hasil yang luar biasa maka kita harus menjalani suatu proses yang luar biasa; e) Semua faktor yang telah disebutkan sebelumnya harus dilaksanakan dengan menggunakan pengetahuan. Karena itu tidaklah berlebihan jika pengetahuan dikatakan sebagai faktor paling penting dalam mengkatalis perubahan.

\section{Perguruan Tinggi Islam di Aceh Tenggara sebagai Agents of Social Change}

Mahasiswa dalam perguruan tinggi merupakan mahasiswa yang mempelajari ilmuilmu tentang pendidikan agama Islam sebagai salah satu mata pelajaran di sekolah umum mempunyai peranan yang sangat penting, strategis dalam pembentukan moral, akhlak dan etika peserta 
didik yang sekarang ini sedang berada pada titik terendah dalam perkembangan masyarakat. Peran pendidikan agama Islam untuk membuat dan menciptakan peserta didik yang berkarakter atau berkepribadian yang islami, semua itu tidak lepas dari kelemahan aktor utama dalam proses pendidikan agama Islam di kelas, yakni kelemahan guru agama Islam dalam pelaksanaan proses pembelajaran di sekolah. Di sinilah jelas terlihat bagaimana perguruan tinggi mencetak kader-kader yang memiliki keilmuan di bidang pendidikan Islam. Baik pembinaan terhadap mahasiswa di bidang pengajaran maupun manajemen lembaga pendidikan maupun kurikulum pendidikan.

Mahasiswa harus melakukan penguatan posisi dan peran guru di kelas secara terus menerus sehingga tercipta penggerak dan suasana keagamaan yang kondusif di kelas. Mutu pendidikan agama Islam di kelas meliputi keseluruhan komponen, baik yang terlibat langsung dalam proses pembelajaran maupun komponen penunjang lainnya yang kiranya sangat penting bagi keberhasilan dalam pembinaan keperibadian mahasiswa secara umum. Di sisi lain, mahasiswa juga harus dapat memberikan pengelolaan yang efektif dan efesien terhadap lembaga madrasah. Karena dengan pengelolaan yang baik maka madrasah akan terbentuk menjadi lembaga yang menghasilkan lulusan yang berkompeten. Dalam kontek pendidikan agama Islam di sekolah berarti bahwa kendali mutu diarahkan pada usaha perbaikan terhadap kebutuhan belajar. Dengan kata lain terfokos pada pembelajaran ini sangat penting dalam rangka memberikan ilmu-ilmu yang bermanfaat, dengan kualitas yang ditetapkan, maka proses pembelajaran harus terobsesi untuk memenuhi atau melampaui standart mutu atau kualitas yang diharapkan, dengan demikian maka semua sekolah berkompetisi untuk mencapai standart mutu yang ditetapkan tersebut.

Sebagai agen perubahan, mahasiswa tidak hanya menjadi penggagas perubahan, melainkan menjadi objek atau pelaku dari perubahan tersebut. Sikap kritis mahasiswa sering membuat sebuah perubahan besar. Sebagai mahasiswa seharusnya berpikir untuk mengembalikan dan mengubah semua ini. Perubahan yang dimaksud tentu perubahan ke arah yang positif dan tidak menghilangkan jati diri kita sebagai mahasiswa. Dalam konteks pendidikan agama Islam, perguruan tinggi Islam memberikan pembinaan keterampilan, kognitif dan efektif, yang merupakan suatu yang rumit karena menyangkut rasa iman dan rasa beragama pada umumnya. Jadi, jika perguruan tinggi memiliki lulusan yang bermutu, maka secara tidak langsung akan mencetak kader-kader generasi yang bermutu di masyarakat. Lulusan inilah yang berperan mengisi pembangunan di masyarakat Aceh Tenggara khususnya.

Mahasiswa merupakan suatu kelompok dalam masyarakat yang memperoleh statusnya karena ikatan dengan perguruan tinggi. Mahasiswa juga merupakan calon intelektual atau cendekiawan muda dalam suatu lapisan masyarakat yang sering kali syarat dengan berbagai predikat. Dari pendapat di atas dapat dijelaskan bahwa mahasiswa adalah status yang disandang oleh seseorang karena hubungannya dengan perguruan tinggi yang diharapkan menjadi calon-calon intelektual. Mahasiswa sebenarnya memiliki peran yang sangat penting dalam kehidupan masyarakat. Sebagai kaum intelektual muda dan sebagai generasi penerus bangsa mahasiswa memiliki peran penting yaitu sebagai "agent of change" karena mahasiswa adalah orang yang seharusnya dapat membawa perubahanperubahan yang berdampak positif dan membangun dalam kehidupan masyarakat serta mampu menanamkan nilai-nilai positif terhadap masyarakat. Sehingga peran mahasiswa yang sebenarnya dapat dirasakan oleh masyarakat.

Perguruan tinggi adalah sebagai social control, peran ini terjadi ketika ada hal yang tidak beres atau ganjil dalam masyarakat. Pelaksanaan pendidikan agama Islam dalam perguruan tinggi bukan hanya menjadikan manusia yang pintar dan terampil, akan tetapi jauh daripada itu adalah untuk menjadikan manusia yang memiliki moral dan akhlakul karimah. Dengan moral dan akhlakul karimah yang dimilikinya akan mampu mengarahkan minatnya untuk terus belajar mencari ilmu. Para ahli pendidik Islam telah sepakat bahwa maksud dari pendidikan dan pengajaran bukanlah memenuhi otak anak didik tetapi maksudnya adalah mendidik akhlak dan jiwa mereka, dengan kesopanan yang tinggi, rasa fadilah (keutamaan), mempersiapkan mereka untuk kehidupan yang seluruhnya ikhlas dan jujur. 


\section{Peran Mahasiswa Perguruan Tinggi Islam di Aceh Tenggara}

Pada dasarnya perguruan tinggi Islam adalah wadah untuk mempelajari ilmu-ilmu yang berguna bagi nusa dan bangsa, khususnya lagi untuk Aceh Tenggara. Lembaga pendidikan memadukan antara ilmu agama dan ilmu umum. Lembaga ini berperan serta memberikan tambahan pelajaran agama pada sekolah-sekolah umum di kalangan masyarakat Aceh Tenggara.

Berdasarkan data yang didapatkan dalam PDDIKTI mulai tahun 2013 Aceh Tenggara sudah memiliki dua perguruan tinggi Islam, yaitu Sekolah Tinggi Ilmu Tarbiyah Babussalam (STITBA) yang terdiri dari 2 program studi Manajemen Pendidikan Islam (MPI) dan Pendidikan Guru Madrasah Ibtidaiyah (PGMI). Perguruan tinggi Islam yang kedua adalah Sekolah Tinggi Agama Islam Sepakat Segenep (STAISES) yang memiliki program studi Pendidikan Agama Islam (PAI), Hukum Ekonomi Islam (HES), dan Pendidikan Guru Raudatul Atfal (PGRA).

Di Kabupaten Aceh Tenggara khususnya, peran perguruan tinggi sangatlah sentral. Perguruan tinggi merupakan tempat penyiapan sumber daya manusia untuk mendukung pembangunan daerah, baik dari tenaga madya yang terampil, para pemikir, maupun para ilmuwan peneliti yang handal. Tanpa mengenyampingkan perguruan tinggi umum, perguruan tinggi Islam di Kutacane sudah banyak melahirkan tenaga pendidik, baik guru SD, SMP, dan SMA, Pegawai di Instansi Daerah ada juga para alumni sudah mendirikan yayasan (Wawancara Sufyan Husni Ketua STAISES). Ini merupakan hal yang baik karena yang mengembangkan daerah merupakan putra daerah sendiri. Di sisi lain, jika mahasiswa dibekali dengan keilmuan yang baik dan mandiri, maka masyarakat akan akan menjadi lebih dekat dengan pendidikan. Karena dengan pendidikanlah budaya suatu daerah dapat menjadi estafet bagi generasi penerus dan juga untuk memajukan daerah mereka sendiri dan memberi kontribusi bagi negara umumnya.

Mahasiswa sebagai generasi penerus bangsa diharapkan mengoptimalkan perannya memiliki kemampuan, keterampilan, dan akhlak mulia untuk menjadi calon pemimpin siap pakai. Mahasiswa tidak cukup jika hanya sebagai akademisi intelektual yang hanya duduk mendengarkan dosen dalam ruangan perkuliahan, melainkan memperkaya diri dengan pengetahuan, baik itu dari segi keprofesian maupun kemasyarakatan.

Pada dasarnya mahasiswa pada perguruan tinggi mewujudkan suasana belajar dan peroses pembelajaran agama peserta didik secara aktif mengembangkan potensi dirinya untuk memiliki kekuatan spritual keagamaan, pengedalian diri, kepribadian, kecerdasan, akhlak mulia serta keterampilan yang diperlukan dirinya masyarakat dan bangsa, negara.

Perguruan tinggi Islam di Aceh Tenggara dalam mewujudkan perannya membentuk suatu organisasi yang dinamakan LDK (Lembaga Dakwah Kampus). Lembaga ini dibentuk untuk mempermudah kegiatan-kegiatan kampus untuk berkontribusi melakukan pengabdian kepada masyarakat. Mahasiswa-mahasiswanya senantiasa berbagi ilmu kepada kalangan masyarakat Aceh Tenggara, seperti berdakwah di masjid, mengajarkan anak-anak mengaji dan lain sebagainya. Selain itu, mahasiswa juga sering turun ke lapangan membantu bergotong royong apalagi yang tertimpa musibah seperti kebakaran, kebanjiran dan gempa bumi. Di sisi lain organisasi kemahasiswaan juga berperan penting dalam kegiatan kemasyarakatan di samping mata kuliah KPM yang merupakan kegiatan setiap tahunnya dilakukan mahasiswa untuk mengabdi di masyarakat.

Mahasiswa-mahasiswa tersebut sangat kreatif dan cerdas dalam melaksanakan perannya sebagai mahasiswa. Mahasiswa-mahasiswa juga sering membagikan ilmu-ilmu yang bermanfaat tentang soal-soal agama maupun pengetahuan umum, sehingga masyarakat bisa mengamalkannya dalam perilaku kehidupan sehari-hari, baik di lingkungan keluarga maupun tempat bekerja. (Observasi peneliti tanggal 20 Agustus 2018)

Salah satu kegiatan mahasiswa yang dilakukan di beberapa daerah di Aceh Tenggara adalah yang sederhana dilihat, yaitu menghidupkan kegiatan pengajian anak-anak, pengajian remaja, dan perwiritan ibu-ibu. Kegiatan ini adalah hal yang rutin dilakukan oleh para mahasiswa. Di sisi lain mahasiswa juga menghidupkan lembaga pendidikan Raudatul Atfal. Walaupun kegiatan ini adalah sederhana tetapi masyarakat sangat antusias dan memberikan apresiasi. 
Ketika mahasiswa STAISES yang KKN dijemput, berbagai apresiasi diberikan oleh masyarakat. Bahkan ada mahasiswa yang diminta kepala desa setempat untuk tetap tinggal menghidupkan lembaga pendidikan yang ada. Di sinilah terlihat adanya perubahan sosial masyarakat terhadap pendidikan seperti yang dijelaskan oleh sebagai berikut: 1) Di masyarakat perguruan tinggi Islam dapat mengembangkan sikap universal bukan sikap yang partikularis.; b) Perguruan tinggi Islam dapat mempersatukan dan memperkuat kebudayaan masyarakat; c) Perguruan tinggi sebagai pembentukan moral yang tinggi dengan penuh perhatian berusaha menanamkan akhlak mulia, meresapkan keutamaan-keutamaan dalam jiwa para siswanya yang merupakan bagian dari warga masyarakat, membiasakan mereka berpegang pada moral yang tinggi dan menghindarkan hal-hal tercela, berfikir rohaniyah dan insaniyah, serta menggunakan waktu untuk belajar ilmu duniawi dan ilmu-ilmu keagamaan; d) Dapat mengembangkan sikap-sikap komunikasi dan silaturrahmi dengan kesediaan diri untuk mau mengerti dan mau belajar dengan pihak lain di lingkungan masyarakat (Wawancara dengan Masyarakat Kecamatan Engkran).

\section{Peran Mahasiswa sebagai Pembinaan Generasi Muda}

Anak-anak merupakan bagian dari masyarakat yang memiliki peran penting untuk generasi selanjutnya. Di tangan merekalah wujud dari wajah suatu masyarakat di masa depan. Jika di usia anak-anak mereka sudah tertanam pendidikan dan budi pekerti, maka untuk yang akan datang mereka menjadi generasi yang berkualitas. Ini sesuai dengan harapan warga Aceh Tenggara yang berkeinginan bahwa generasi penerus mereka tidak boleh sama dengan mereka sama yang belum mengecap pendidikan. Mereka ingin kampung halaman mereka dikenal oleh masyarakat luar dengan nama yang baik. Ini tidak mungkin terjadi jika masyarakat acuh-tak acuh dengan pendidikan itu sendiri. Maka dengan adanya perguruan tinggi, generasi yang terdidik dapat memberikan konstribusi untuk mewarnai masyarakat dengan ilmu dan kebudayaan.

Anak-anak memiliki rasa ingin tahu membuatnya mencari informasi melalui media komunikasi (internet). Manakala jiwanya gersang dari agama, maka akan membuat anak didik justru melihat hal-hal yang berbau pornografi/aksi. Di saat itu pikirannya teransang dan dikuasai nafsu syahwat yang akan mendorongnya untuk mencobacoba apa yang disaksikannya. Akhirnya, tindakan amoral/asusila pun terjadi dan sering dilakukan oleh anak-anak yang masih berumur dini. Bila ditarik titik permasalahan yang signifikan terhadap munculnya dekadensi moral anak-anak hari ini adalah tidak maksimalnya pendidikan agama diajarkan kepada para siswa, khususnya sejak usia di Sekolah Dasar (SD). Muatan pelajaran agama di Sekolah Dasar (SD) sangat minim untuk menjadi bekal mereka menghadapi kacau dan semrawutnya hiruk pikuk dunia ini.

Dari uraian di atas jelaslah bahwa pembinaan dan bimbingan melalui pendidikan agama terhadap anak-anak sangat besar pengaruhnya bagi masyarakat sebagai alat pengontrol dari segala bentuk sikap dan tingkah lakunya dalam kehidupan sehari-hari, artinya nilainilai agama yang diperolehnya menjadi bagian dari pribadinya yang dapat mengatur segala tindak tanduknya secara otomatis. Kaitannya dengan meminimalisir dekadensi moral sangat besar sekali. Pendidikan agama mengarahkan kepada setiap siswa untuk komitmen terhadap ajaran agamanya. Tidak terbuai dengan lingkungan yang tidak baik. Tidak berperilaku buruk dalam setiap aktivitasnya. Masyarakat harus segera disadarkan bahwa ancaman global khususnya kemajuan tekhnologi informasi dan komunikasi kalau tidak dibarengi dengan benteng ilmu agama akan berakibat fatal terhadap lajunya perilaku dekadensi moral. Rendahnya kemampuan memfilter mana yang baik dan mana yang tidak baik inilah yang akan memunculkan berbagai tindakan penyimpangan anak-anak didik.

Pada hakikatnya belajar harus berlangsung sepanjang hayat untuk menciptakan generasi yang berkualitas, pendidikan harus dilakukan sejak usia dini dalam hal ini melalui pendidikan anak usia dini (Paud), yaitu pendidikan yang ditujukan bagi anak sejak lahir hingga usia enam tahun. Pentingnya pembinaan anak pada usia yang masih aktif ini merupakan keniscayaan, prodi PGMI dan PGRA menjadi sangat penting mengingat potensi kcerdasan dan dasar-dasar perilaku seseorang terbentuk pada rentang usia dini. Sedemikian pentingnya masa ini sehingga usia dini sering 
disebut the golden age (usia emas). Sistem pendidikan di Indonesia terdiri dari pendidikan anak usia dini, pendidikan dasar, pendidikan menengah dan pendidikan tinggi yang keseluruhannya merupakan kesatuan sistematis. Paud diselanggarakan sebelum jenjang pendidikan dasar, paud dapat di selanggarakan melalui jalur pendidikan formal, nonformal atau informal, paud pada jalur pendidikan formal berbentuk teman kanak-kanak (TK) atau bentuk lain sederajat, paud pada jalur pendidikan nonformal berbentuk kelompok bermain (KB), teman penitipan anak (TPA). Sedangkan PGMI lanjutan dari pendidikan anak pada usia dini.

Ini sejalan dengan keluh kesah dari perangkat masyarakat bahwa dengan mewabahnya warnet sekarang keinginan anak-anak untuk bermain internet tidak terbendung lagi. Hal ini berdampak kepada sifat anak-anak yang tidak terkontrol lagi ke arah tidak baik. Hal ini harus dicari solusi yang tepat dan cepat agar perilaku ini menjadi budaya. Peran mahasiswa di sini adalah membuat suatu solusi yang dapat mengimbangi minat anak-anak terhadap internet.

Salah satu hal yang pernah dilakukan oleh mahasiswa STAISES ketika KKN di Desa Lawe Bulan adalah dengan membuat kelompok belajar berbasis IT. Di sini terlihat antusias anak-anak untuk mengikuti kegiatan belajar tersebut dan bahkan kepala desa setempat membuat kegiatan tersebut menjadi permanen. Majunya suatu daerah jika masyarakatnya memiliki kecintaannya terhadap pendidikan. Sejalan dengan pemikiran Ketua STAISES pak Sofyan Husni Salam bahwa STAISES sudah melahirkan lebih dari 800 alumni yang telah berkecimpun di berbagai lembaga di Aceh Tenggara. Hal ini memberi gambaran bahwa sudah ada 800 orang lebih generasi Aceh Tenggara memberikan pembinaan generasi muda.

Pendidikan agama yang menyajikan kerangka moral sehingga seseorang dapat dapat membandingkan tingkah lakunya. Pendidikan agama yang terarah dapat menstabilkan dan menerangkan mengapa dan untuk apa seseorang berada di dunia ini. Pendidikan agama menawarkan perlindungan dan rasa aman, khususnya bagi para siswa dalam menghadapi lingkungannya. Agama merupakan salah satu faktor pengendalian terhadap tingkah laku anak-anak didik hari ini. Hal ini dapat dimengerti karena agama mewarnai kehidupan masyarakat setiap hari.

Dengan pendidikan yang diberikan diharapkan anak dapat tumbuh sesuai dengan potensi yang dimilikinya, sehingga kelak dapat menjadi anak bangsa yang diharapkan. Pembelajaran pada anak usia dini dan dasar harus menggunakan konsep terpadu yang dilakukan melalui tema. Tema yang dibangun harus menarik dan dapat membangkitkan minat anak, agar anak mau mengenal sebagai konsep secara mudah dan jelas sehingga pembelajaran menjadi mudah dan bermakna bagi anak, mengembangkan keterampilan hidup anak dapat dilakukan melalui sebagai peroses pembiasaan. Hal ini dimaksudkan agar anak belajar mandiri dan bertanggung jawab serta disiplin. Pembelajaran anak usia dini hendaknya dilakukan secara berhadap, dimulai dari konsep yang sederhana dan dekat dengan anak. Keterlibatan orang tua sebagai pendidikan utama sebagai anak. Oleh karna itu peran orang tua dalam mendidik anak usia dini sangat penting dalam pelaksaan pendidikan. Mengembangkan standar kompetensi anak, pembelajaran awal dilakukan dalam beberapa tahap, yaitu: a) Pengenalan diri sendiri (perkembangan konsep diri); b) Pengenalan pelaksanaan (perkembangan emosi); c) Pengenalan tentang orang lain (perkembangan sosial); d) Pengenalan sebagai gerak (perkembangan fisik); e) Mengembangkan komunikasi (perkembangan bahasa); f) Keterampilan berfikir (perkembangan kognitif)

\section{SIMPULAN}

Pendidikan tinggi merupakan suatu lembaga bagi mahasiswa untuk menggali ilmu pengetahuan melalui pendidikan, penelitian dan pengabdian masyarakat. Dengan tridarma perguruan tinggi ini mahasiswa dapat memberikan kontribusi bagi masyarakat agar budaya masyarakat dapat berkesinambungan antar satu generasi dengan generasi selanjutnya

Perguruan tinggi Islam sebagai pembinaan generasi muda diharapkan mengoptimalkan perannya memiliki kemampuan, keterampilan, dan akhlak mulia untuk menjadi calon pemimpin siap pakai. Mahasiswa tidak cukup jika hanya sebagai akademisi intelektual yang hanya duduk mendengarkan dosen dalam ruangan perkuliahan. Melainkan memperkaya diri dengan pengetahuan 
baik itu dari segi keprofesian maupun kemasyarakatan.

Perguruan Tinggi Islam di Aceh Tenggara Sebagai Agents of Social Change mempunyai peranan yang sangat penting, strategis dalam pembentukan moral, akhlak dan etika peserta didik yang sekarang ini sedang berada pada titik terendah dalam perkembangan masyarakat. Peran pendidikan Islam untuk membuat dan menciptakan peserta didik yang berkarakter atau berkepribadian yang Islami, yang merupakan bagian dari masyarakat.

\section{DAFTAR PUSTAKA}

Abbas, S. (2008). Manajemen Perguruan Tinggi. Jakarta: Kencana.

Al-Syaibani, O.M.A. (1979). Falsafah Pendidikan Islam. Jakarta: Bulan Bintang.

Daulay, H.P. (2001). Modernisasi Islam: Tokoh Gerakan dan Gagasan, Bandung: Cipta Pustaka Media.
Halim, M.N.A. (2001). Anak Saleh Dambaan Keluarga. Jakarta: Mitra Pustaka.

Langgulung, H. (1986). Manusia dan Pendidikan. Jakarta: Pustaka Al Husna

Langgulung, H. (1987). Asas-asas Pendidikan Islam. Jakarta: Pustaka Al Husna.

Mujib, A. \& Muzakir, J. (2006). Ilmu Pendidikan Islam. Jakarta: Prenada Media Group.

Mustajib, H. (2016). Filsafat Pendidikan Hasan Langgulung. El Tarbawi: Jurnal Ilmu-ilmu Pendidikan. IX (2).

Nizar, S. (2005), Sejarah dan Pergolakan Pemikiran Pendidikan Islam. Ciputat: Quantum Teaching.

Suharyanto, A., Armansyah M., Taufik W.H., (2016), Aktualisasi dan Filosofi Konsep Kepemimpinan Tradisional Bagi Generasi Muda di Bale Marojahan Medan, Jurnal Pendidikan Ilmu-Ilmu Sosial, 8 (2) (2016): 182-189

Thoha, M. (2007). Perilaku Organisasi, Konsep Dasar dan Aplikasinya. Raja Grafindo Persada, Jakarta.

Walidin, W. (2003). Konstelasi Pemikiran Ibnu Khaldun. Lhokseumawe: Nadiya Foundation. 